\title{
NEWS LETTER
}

\section{British Columala Drvision}

Tre Britshr Columbia Drvision of the Canadian Anaesthetists' Society has completed another active and satisfying year. Programmes for the monthly meetings were as follows:

September, 1965 General Business Meeting.

October, 1965 Speaker: Doctor Harold Rice, Director of the Clinical Investigation Unit, St. Paul's Hospital, Vancouver

Subject: "The Physiology of the Central Venous Pressure and its Clinical Application"

November, 1965 Speaker: Doctor A. W. Conn, Director of Anaesthesia, Sick Childrens' Hospital, Toronto

Subject: "The Role of Humidification in Paediatric Anaesthesia"

January, 1966 Speaker: Doctor W. G. Trapp, Department of Surgery, University of British Columbia

Subject: "Hyperbaric Oxygen"

February, 1966 Speaker: Dr. Sidney Segal, Department of Paediatrics, University of British Columbia

Subject: "Recent Advances in the Oxygenation of Neo-nates"

March, 1966 Speaker: Doctor W. A. Young, Department of Clinical Investigation, St. Paul's Hospital, Vancouver

Subject: "Problems Associated with Pressurization and Decompression"

April, 1966 The final meeting of the year consisted of a weekend meeting in Victoria. The guest speaker at the Clinical Session was Doctor F. D. Milligan, Victoria, who spoke on "Modern Concepts of Liver Toxicity." The meeting terminated with a successful dinner dance at the Victoria Golf Club.

\section{News Items}

Doctor A. S. Carballo, who completed his training at The University of British Columbia, has joined the staff of the Royal Columbian Hospital, New Westminster, B.C.

Doctor H. T. Davenport, formerly Director of Anaesthesia at the Childrens' Hospital, Montreal, has joined the staff of the Vancouver General Hospital and University of British Columbia. 
Doctor Michael Falk, who formerly practiced in Prince George, B.C., has joined the staff of the Richmond General Hospital, Richmond, B.C.

Doctor Peter Klassen has established a private practice of anaesthesia in Vancouver, associated with Doctor E. J. Treloar in the Fairmont Medical Building, specializing in anaesthesia for out-patient and dental surgery.

Doctor Douglas Gardiner, formerly practicing in Nanaimo, B.C., has established a private practice of anaesthesia in New Westminster, B.C.

Doctor H. V. Towell, who completed his training at the University of British Columbia, has joined the staff and Department of Anaesthesia of the Methodist Hospital, Houston, Texas.

Doctor Watson MacCrostie, formerly on the staff of St. Vincent's Hospital, Vancouver, has joined the staff of the Department of Anaesthesia, Richmond General Hospital, Richmond, B.C.

The Annual Refresher Course sponsored by the staff of the Vancouver General Hospital and the University of British Columbia, was held in March, 1966. The Guest Speaker was Doctor Max Minuck, Director of Anaesthesia, St. Boniface General Hospital, St. Boniface, Manitoba. Thirty registrants from British Columbia and Alberta, and the States of Washington and Oregon registered on the Course.

Doctor Eric Webb has returned to the staff of the Vancouver General Hospital and The University of British Columbia, following two years' leave of absence during which time he was on the staff of the University of Lagos, Nigeria.

Doctor A. B. Mulholland, formerly on the staff of the Royal Infirmary, Aberdeen, Scotland, has joined the staff of the Vancouver General Hospital and the University of British Columbia.

At the recent elections of the Vancouver Medical Association, Doctor H. B. Graves was elected President-Elect, and Doctor W. A. Dodds, Honorary Treasurer of this Association.

The new officers of the British Columbia Division, Canadian Anaesthetists' Society, for the year July 1, 1966 to June 30, 1967, are:

\section{Chairman}

Vice-Chairman

Secretary-Treasurer

Chairman, Economics Committee

Chairman, Programme Committee

Members-at-Large
Dr. G. J. Fyffe

Dr. F. G. Williams

Dr. P. W. Hudson

Dr. N. R. J. McMillen

Dr. I. S. Paterson

Dr. A. K. Gibbons

Dr. E. Forseng

Dr. R. G. Whitehead (Vancouver Island)

Arrangements are being completed for a Joint Annual Meeting with the British Columbia Division of the Canadian Anaesthetists' Society and the Washington State Society of Anaesthesia. 